\title{
Curriculum-Engaged School Libraries and Teacher Librarians Value Curriculum-Alignment of Resources
}

\author{
Dr Ben Chadwick \\ Manager, SCIS \\ Education Services Australia \\ PO Box 177, Carlton South, Vic \\ Australia, 3053 \\ ben.chadwick@esa.edu.au
}




\begin{abstract}
Australian school libraries have an expressed need to organise resources according to Australian Curriculum (AC) outcomes.

The Schools Catalogue Information Service (SCIS) at Education Services Australia creates and distributes MARC records to $93 \%$ of Australian school libraries, but has not traditionally provided curriculum-alignment data.

This paper describes a SCIS survey of 586 Australian school libraries, examining the factors driving demand for curriculum alignment. Libraries with a teacherlibrarian and those that were already actively engaged in curriculum resourcing saw the most value in resource alignment.

Curriculum-engaged libraries were more prominent in secondary schools, Catholic schools, and large schools with larger libraries and a teacher-librarian. They were also more prominent in schools where teachers actively engaged with library staff. Library engagement is discussed as a concept of potential interest for further research.

Keywords: Curriculum Alignment, School Libraries, Australian Curriculum, Education Resources, Teacher Librarians
\end{abstract}




\section{Introduction}

The Schools Catalogue Information Service (SCIS), a business unit of Education Services Australia (ESA), is investigating methods for delivering curriculum-alignment metadata to school libraries. Whilst surveys suggest a strong desire for this kind of service (Kennedy, 2013), it is not clear whether this desire is driven by school libraries broadly or by particular subsets.

This paper examines and defines resource alignment, and places it in the context of the unfolding Australian Curriculum (AC) and the need to resource that curriculum. It then explores the notion of the curriculum-engaged library, which actively evaluates its collection against curriculum objectives and collaborates with teaching staff to resource the curriculum. It describes a survey undertaken by SCIS, which sought to examine the nature of curriculum-engaged libraries and other factors impacting school libraries' perception of the value of resource alignment.

\section{What is alignment?}

Carr \& Harris (2001) describe alignment in educational contexts as the multiple linkages amongst formal curriculum outcomes, instructional resources, the content and process of teaching, and assessment. Student outcomes are improved when there is greater alignment across these modalities (Squires, 2012). According to the INFOhio Alignment Standard, use of a resource that is aligned to an objective "should result in a measurable increase in students' understanding of concepts or ability to perform skills" (Adamich, 2010).

In this paper, the term 'alignment' will be used to refer to alignment between informational or instructional resources and learning outcomes specified in formal curricula. Alignment will be defined as the act of asserting a connection between a resource and an outcome to the effect that use of the resource per se will result in improvement on assessments designed to measure performance on the outcome.

This definition is consistent with the INFOhio Alignment Standard's conceptualisation, implying that alignments can be subjected to external verification. The validity of an alignment should be measurable as behavioural change: on average, students who use the resource should do better.

The definition further suggests that alignment can only exist if the resource improves learning independently of the intervention or guidance of an instructor (this does not imply that the resource cannot be used within the context of an interaction between a learner and instructor, or that doing so would likely improve the learning impact of the resource). For example, a card contains the words "brief" and "ceiling" with the letter combinations 'ie' and 'ei' in red text. A primary student, without a teacher's intervention, could use such a resource 
to learn about those letter combinations. It could also be used in a numeracy exercise such as counting the letters in each word, however without the guidance of an instructor it is unlikely to be used in that way.

\section{Curriculum Resourcing and Australian School Libraries}

After the 2008 Melbourne Declaration on Educational Goals for Young Australians, the Australian Curriculum and Reporting Authority (ACARA) was established to implement and publish Australia's first national curriculum (Australian Curriculum and Reporting Authority [ACARA], 2015a).

The Australian Curriculum provides a common set of learning outcomes for Australian jurisdictions and educational bodies. Version 8.1 of the AC's F-10 Curriculum was approved by the Education Council on 18 September 2015 (ACARA, 2015a). It represents:

... a progression of learning from Foundation - Year 10 that makes clear to teachers, parents, students and others in the wider community what is to be taught, and the quality of learning expected of young people as they progress through school. (ACARA, 2015b)

Discipline-specific subject matter is organised within structural layers, with the top layer being the eight learning areas English, Mathematics, Science, Health and Physical Education, Humanities and Social Sciences, The Arts, Technologies, and Languages. The 'building blocks' of the AC are the content descriptions, which are the outcomes describing what is to be learnt at a given grade or in a band of grades (see Figure 1).

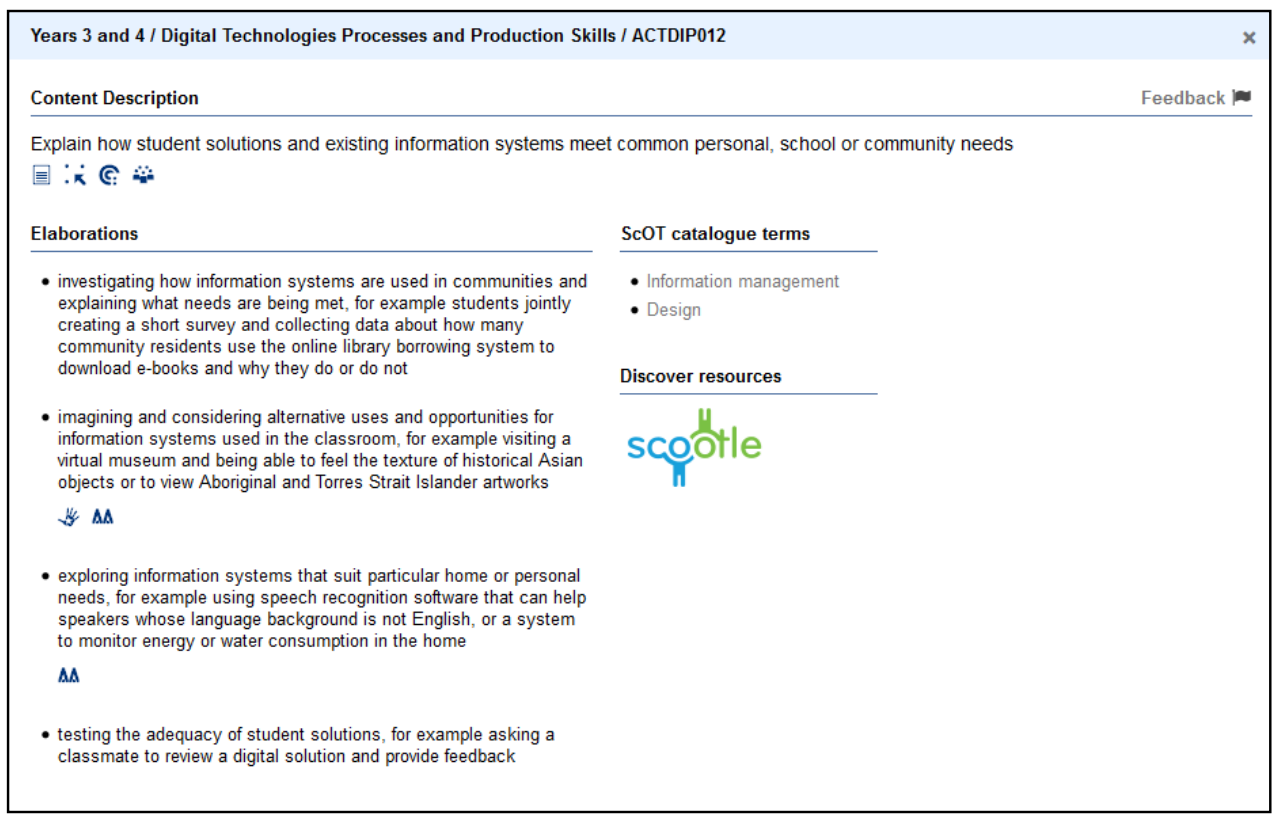

Figure 1. Website screenshot of AC Content Description ACTDIP012 
Each of the eight Australian states and territories are responsible for their own timeframe and method of implementing the AC. As of 2016, each is implementing the AC or transitioning to use of the AC. Some (notably New South Wales and Western Australia) are implementing the $A C$ by updating local syllabi or curricula to incorporate $A C$ outcomes (ACARA, 2015b).

As well as differing jurisdictional policies and timeframes, the extent and nature of AC adoption in schools will be impacted by differences in school culture and leadership (eg Batiste, Walker \& Smeed, 2015).

\section{Resourcing the Australian Curriculum}

ACARA seeks to support adoption of the AC in Australian schools by "developing materials to support teachers as the curriculum is being implemented" (ACARA, 2015a). ESA, a notfor-profit ministerial company owned by all Australian education ministers, works with ACARA to create, publish, and disseminate curriculum materials. Since 2011, ESA has done significant work aligning digital education resources to the $A C$ as part of the National Digital Learning Resource Network.

The 2014 Review of the Australian Curriculum (Australian Government, 2014) reiterated an ongoing need for "content designed to be pedagogy-enhancing", and noted ESA's role in supporting this. More recently, the Education Council's 2015 National STEM School Education Strategy (Education Council, 2015) reinforced the importance of "uptake of online learning materials, linked to classroom practice", and emphasised that "effort under the national strategy will build on, and link to, the Australian curriculum".

School libraries can play a core role in the school-wide curriculum delivery process through strategic and responsive resourcing of the curriculum. As early as 2003, the Ministerial Council on Education, Employment, Training and Youth Affairs' ICT in Schools Taskforce (Ministerial Council on Education, Employment, Training and Youth Affairs [MCEETYA], 2003) acknowledged the role of libraries and library systems in delivering curriculum-aligned resources, stating that "it is highly desirable that the system that enables teachers to plan lessons or units of work online also enables them to seamlessly discover resources from a local educational repository or from school library collections" (p20-21).

No such systematic, comprehensive library collection solution has yet been forthcoming, but there appears to be high demand for such a service. In an earlier SCIS survey of 300 school library staff (Kennedy, 2013), respondents listed "Resources linked to the Australian Curriculum" as the most desirable of a range of possible services, with $78 \%$ rating it as of 
"High value". This has been a consistent message - it recurs in the annual Softlink surveys, which ask school libraries to rate their most important objectives. In the 2015 survey, "Aligning Australian Curriculum (ACARA) with existing resources/practices" was the highest rated objective, with $89 \%$ of respondents rating it as 'Important' or 'Very important' (Softlink Australia, 2015).

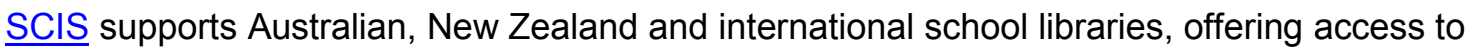
the largest database of school-related catalogue records in the Southern Hemisphere. In Australia, approximately $93 \%$ of Australian schools obtain MARC-21 records for their local systems by importing them from SCIS.

To date, resource alignment has not been a part of SCIS's mandate. However, it is well placed to offer such a service given the proportion of schools that obtain MARC records from the SCIS central database, and this would be in keeping with the foundational purpose of SCIS to mitigate the cataloguing burden on school libraries by cataloguing 'once for everybody'.

\section{Curriculum-Engaged Libraries}

The provision of services to directly support the taught curriculum and the importance of close liaison and shared planning with teaching staff is recognised both nationally and internationally as a core role of school libraries. In the UNESCO/IFLA School Library Manifesto, the first of eight listed goals of school libraries is "supporting and enhancing educational goals as outlined in the school's mission and curriculum" (United Nations Educational, Scientific and Cultural Organization, 2016). In Australia, the first of six 'responsibilities of the school library' in the Australian School Library Association's (ASLA) School Library Bill of Rights is "To provide materials that will enrich and support the curriculum, taking into consideration the varied interests, abilities and maturity levels of the pupils served" (Australian School Library Association [ASLA], 2014).

Teacher-Librarians (TLs), specifically, are identified as having a special role in these processes. The Australian Library and Information Association (ALIA, 2014a), identifies provision of resources and curriculum support as being a core function of TLs, and notes their specialist skills in "ensuring the school library collection supports the school curriculum and community". This capability is emphasised in ASLA/ALIA's Teacher Librarian Practice for the Australian Professional Standards (ALIA, 2014b). Research suggests that TLs are especially involved in 'teaching teams', curriculum planning, and other collaborations with teachers, and that these activities actively contribute to improved student outcomes (Hughes, 2014). 
School libraries and their staff are capable of reducing the significant costs of curriculum planning and resourcing by directing teaching staff to capitalise on the school's existing investment in quality resources, and by positioning the library and its staff as a time-saving resourcing service available to teaching staff (Mitchell, 2011).

Varanasi (2011) notes that in the context of an emerging Australian Curriculum, curriculumengaged libraries will (a) map the collection to the curriculum, identify gaps and assess their significance for professional learning and resourcing needs, and (b) "build on teaching partnerships to provide programming ideas and teaching strategies for the effective use of diverse resources" ( $p 36)$.

Engaged libraries will be proactive in resourcing the curriculum, ensuring staff and students are "served by a locally relevant collection of resources, selected specifically for them from the limitless pool of resources that could [sic] be used to support the Australian Curriculum" (Mitchell, 2011). This can be achieved by a collection gap analysis, such as that described by Lowe, (2001), which includes developing a budgeted collection development plan. In such a case, curriculum-relevant resources can be made findable in the library catalogue, such as by encoding curriculum objectives in MARC records (eg Adamich, 2010), or development of curriculum-mapped collections or current-awareness services.

Engaged libraries will also be responsive to teaching staff, actively collaborating to 'backward map' from curriculum objectives to collection items or acquisitions needs (eg Mackenzie, 2012; La Marca, 2015; Rawson, 2014). Delivering relevant resources back to teachers may involve direct communication or development of reading lists and coursereserves.

The 2013 SCIS survey (Kennedy, 2013) suggested that many school libraries struggle to engage in these ways: respondents felt their collections were not adequately supporting the curriculum and experienced difficulty finding curriculum-appropriate materials. Respondents identified training in resourcing the curriculum as a significant need. These barriers likely relate to scarcity in the usual enabling factors such as budget, staffing, and qualifications and training. It is also likely that library staff will feel less incentive to actively engage with curriculum if they feel teachers do not approach or utilise the library. The 2013 SCIS survey found this to be a common scenario: when asked their three most concerning resourcing issues, the top response (from $47 \%$ or respondents) was "Teachers are not using school resources in their teaching" (Kennedy, 2013). 


\section{Perceived Value of Resource Alignment}

As part of its research, SCIS conducted the current survey to gain a better understanding of the nature of demand for curriculum alignment. Is it uniform across Australian school libraries, or are there specific pockets of libraries driving it?

A set of library-related factors were hypothesised to impact demand for resource-alignment, specifically library engagement. It is proposed that libraries that already actively engage with teaching staff - whether around the AC specifically or teaching and learning more generally - will be more likely to see the benefits in resource alignment. In addition, it is proposed that the presence of a teacher-librarian on staff and larger library staff in general will promote or enable resource-alignment aspirations.

A set of broad school factors are also proposed: school size, sector, and level. In Australia, $71 \%$ of schools are government owned and funded, $18 \%$ are Catholic church schools, and $11 \%$ are privately owned (“Independent”) (Australian Bureau of Statistics [ABS], 2016). Nongovernment schools receive both government and private funding. Primary schools make up $66 \%$ of Australian schools, $15 \%$ are secondary schools, and $14 \%$ are combined primary and secondary schools (also referred to as "K-12") (ABS, 2016).

It is hypothesised that demand for curriculum-aligned resources will be stronger in those schools whose teachers are actively implementing the Australian Curriculum in their daily classroom practice. It is also proposed that libraries will be more disposed toward curriculum-aligned resources if teachers actively approach the library with curriculum resourcing needs.

The current study seeks to explore these factors and assess their impact on school libraries' perception of the value of resource alignment. It begins by describing the proposed schoollevel and library-level predictor variables and their inter-relationships. The notion of a library's curriculum-engagement, and how it relates to other factors is of special interest. The relationship between these and libraries' perceived value of alignment is examined on an individual basis. The distinct factors impacting perceived value are then examined by pooling significant factors from the previous analyses into a single analysis to examine their unique impact on perceived value.

\section{Method}

\section{Survey}

A survey was publicised to all SCIS subscribers via the SCIS newsletter Connections, a notice on the SCIS website, social media posts, and a direct email campaign. Subscribers were informed that one respondent would receive a $\$ 250 \mathrm{AU}$ gift card. 
The survey was designed and published on surveymonkey.com, and was available to be completed between 1 February and 11 March 2016. Items reported in the current paper can be found in Appendix A. All survey question numbers refer to those listed in Appendix A.

A prize winner was selected before data was examined. Identified data was used to remove responses from staff at the same library (see below). Data was then de-identified for analysis.

\section{Predictor Variables}

School enrolment (question three) was measured on a seven-point scale indicating enrolment bands.

School level (question four) was a single-choice item with options Primary, Secondary, Combined Primary/Secondary, and Other.

School sector (question five) was a single-choice item with options Government, Independent, Catholic, and Other.

Question one enquired about the respondent's current role in the library, with the following options: Teacher Librarian; Librarian; Library Technician; School assistant/library officer; Teacher; Principal/Assistant Principal/Other. Question seven enquired about other staff working in the library. It included the same options as question one and enabled respondents to indicate part-time, full-time and casual roles for each.

Teacher-Librarian was a dichotomous variable taken from both question one and question seven, indicating whether or not there was at least one TL on staff in the library.

Library Staff was an indication of the total number of staff in the library, and was measured as the number of roles indicated in question Seven plus the respondent's own role.

Scales were constructed to measure respondents' School Curriculum Activity, Teacher Approach, and Library Engagement, using items from survey questions eight, nine, and ten, respectively. See Appendix B for details of these scales and how they were constructed.

School Curriculum Activity was intended to measure the extent to which teachers in the school were engaged with the Australian Curriculum in their lesson planning, professional evaluation, and use of resources.

Teacher Approach was intended to measure the extent to which teaching staff actively engaged the library for their planning and resourcing needs, including seeking curriculumaligned resources, using the catalogue, and informing the library about their resource needs and lesson planning. 
Library Engagement was intended to measure the extent to which libraries actively resourced curriculum delivery, including compiling resources for teaching staff, liaising with teaching staff about their activities and resourcing needs, and managing the collection with a view to resourcing the school curriculum, including the Australian Curriculum.

Other questions that were not key predictor variables in this paper included question two, asking whether the responded currently worked in the library, and question six, asking about the Australian state or territory in which the school was located.

\section{Outcome Variable}

A scale was constructed to measure respondents' Perceived Value of Alignment (PVA) using items from survey questions 11 to 13 . See Appendix $B$ for details of this scale and how it was constructed.

\section{Results}

All analyses were performed in SPSS Version 24 (IBM, 2016).

\section{Survey response}

Responses were discarded if question two indicated that the respondent was not working in the school library. Two hundred and eighty-four responses with incomplete data were also removed, as indicated by missing data in the final (mandatory) question. An effort was made to remove multiple responses from the same library, as suggested by duplicate IP addresses, school level, enrolments, states or territory, and sector, and confirmed by contact details in the raw (identified) data. In the case of a possible duplicate library, responses from the most qualified respondent were retained. Seven responses were removed in this way.

After this process, 586 responses were retained and used for scale construction (see Appendix B). Figure 2 indicates that responses were received from all Australian states and territories - predominantly New South Wales, Victoria, and Queensland, followed by Western Australia and South Australia. This distribution is roughly representative of population and school distribution across the country.

Responses were predominantly from primary schools (52\%), followed by secondary $(26.6 \%)$ and combined schools (18.25\%). Government schools were the highest responders (60\%), followed by Independent (19.8\%) and Catholic schools (18.4\%). As seen in Figure 3, the largest sub-group of respondents was Government primary schools (37.4\% of total responses), followed by Government secondary (15.9\%) and Independent combined $(11.1 \%)$ schools. 


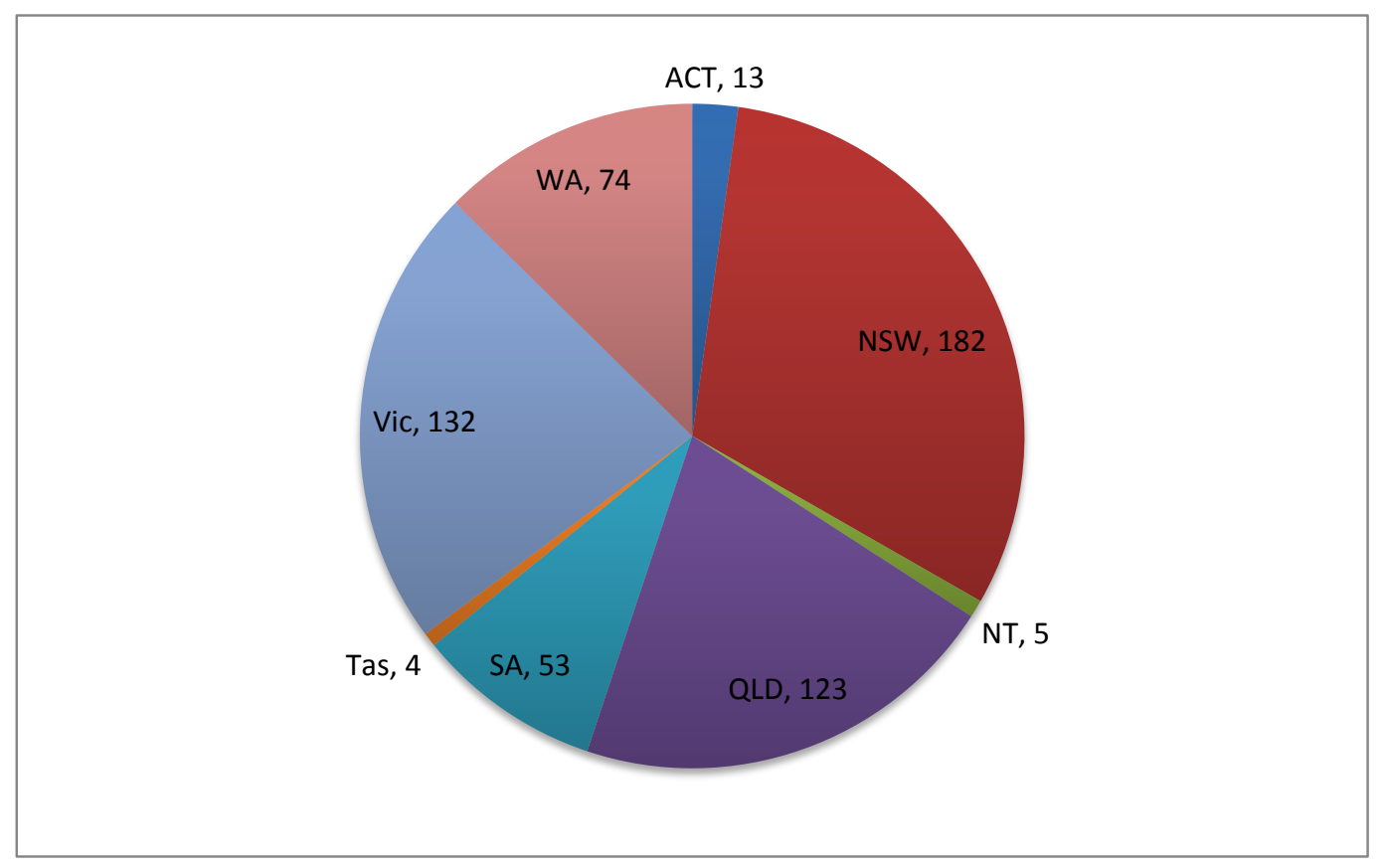

Figure 2. Responses across Australian states and territories

For the analyses described below, 26 responses indicating "Other" for either school sector (question five) or school level (question four) were removed for the purpose of simplifying analyses by reducing levels in those categorical variables.

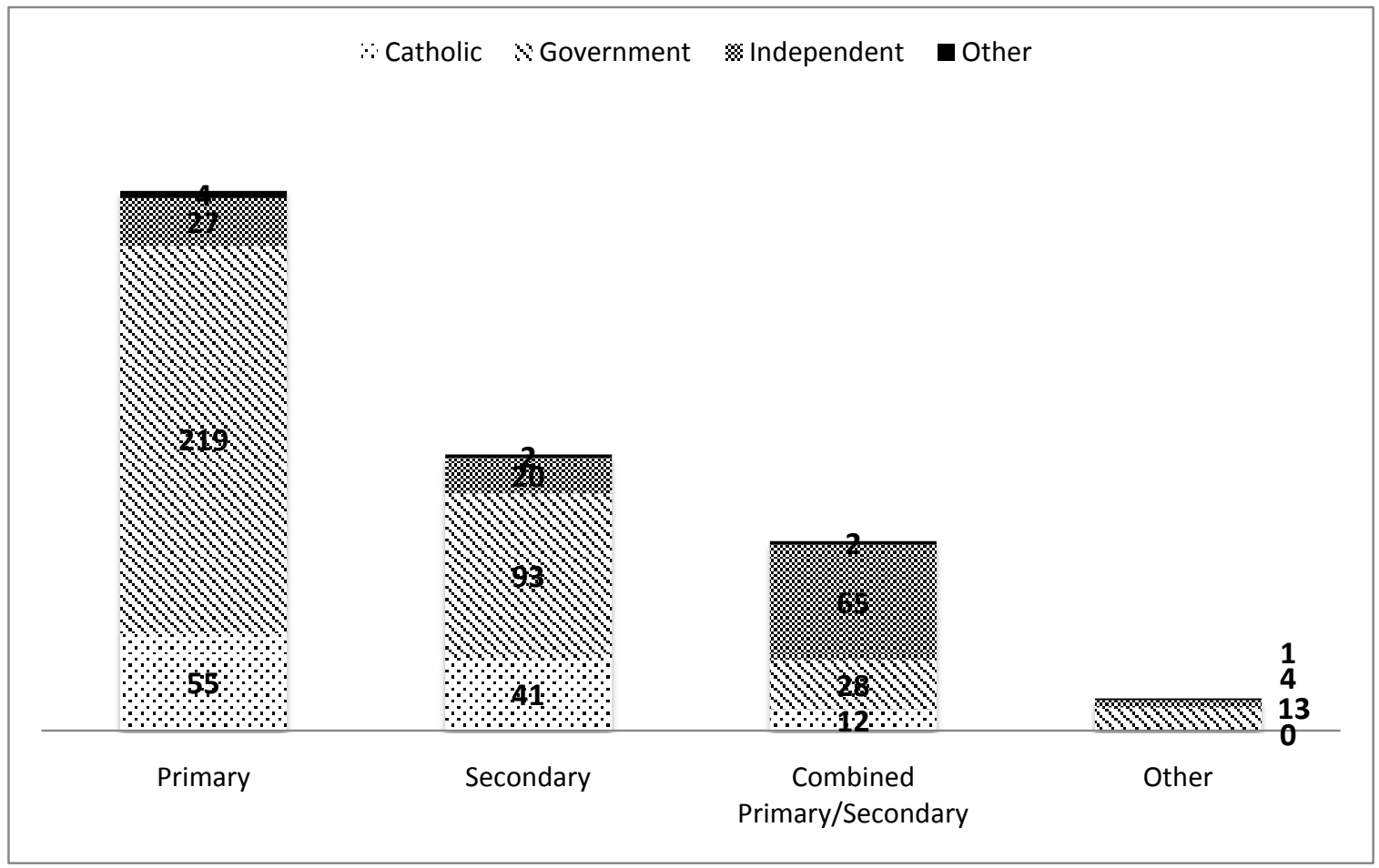


Figure 3. Responses across school sectors and levels

\section{Predictors}

Three indexes were constructed measuring School Curriculum Activity, Teacher Approach, and Library Engagement. Principal Components Analysis was used to confirm the item structure of the indexes, and Cronbach's alpha was used to assess their internal consistency. See Appendix B for details.

The items composing the library engagement scale are displayed in Table 1, along with the number of libraries that reported engaging in the stated practice at least once per term, and correlations with other predictor variables.

The most frequently endorsed practices were to recommend resources to staff (93\%), to research or inquire into staff resourcing needs $(87 \%)$, and to purchase resources aligned to an $\mathrm{AC}$ outcome (85\%).

Table 1. Frequency and simple correlations of raw library engagement items

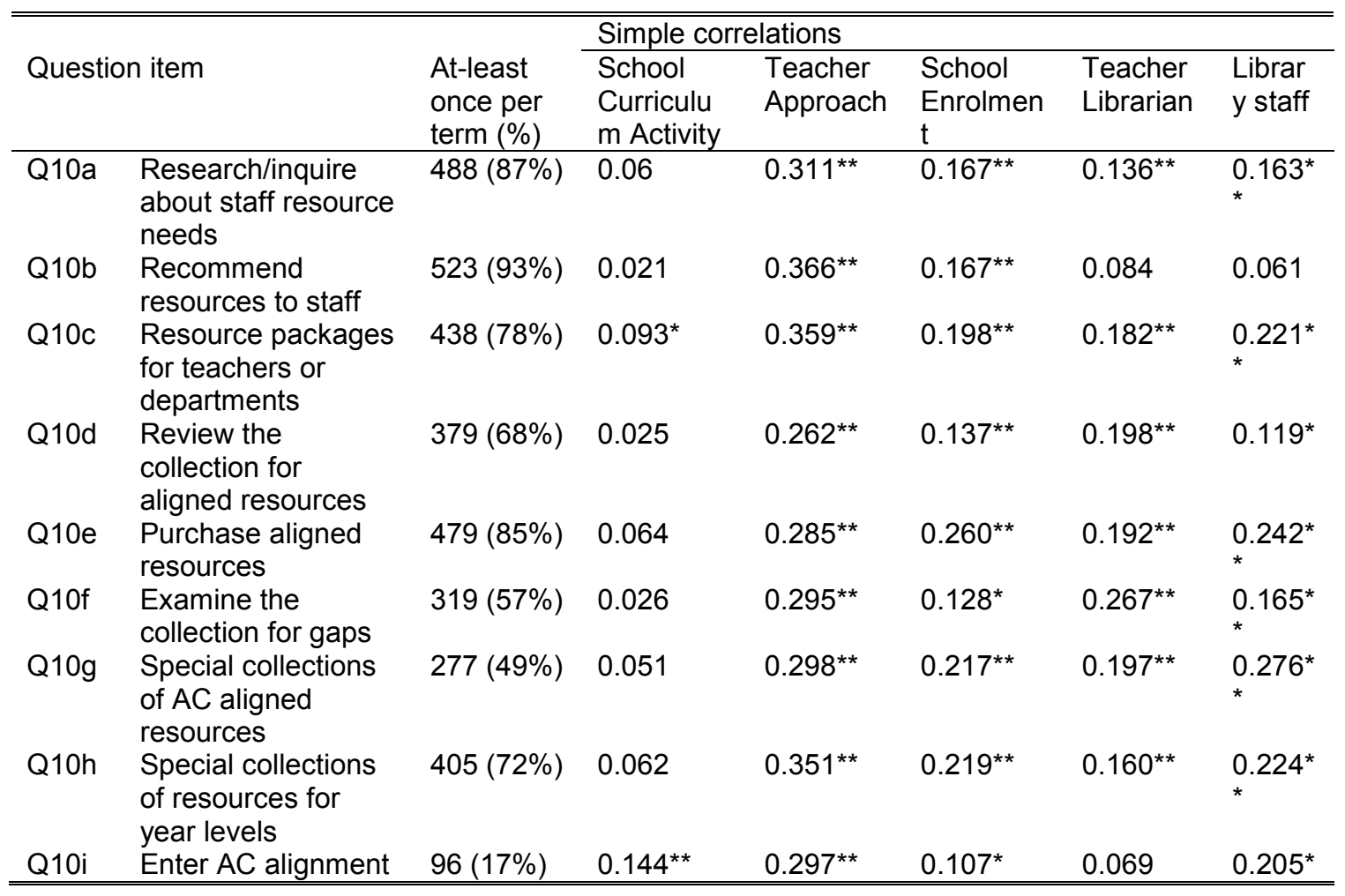


\begin{tabular}{ll}
\hline \hline into the MARC & $*$ \\
records & $*$ \\
\hline \hline
\end{tabular}

** Correlation is significant at the 0.01 level (2-tailed)

* Correlation is significant at the 0.05 level (2-tailed)

Least endorsed practices were to enter AC alignments into local MARC records (17\%), to create special collections of AC-aligned resources (49\%), and to look for gaps by examining the collection against the curriculum (57\%).

All practices were more likely to occur in schools where teachers approached the library, although they were also more likely in larger schools and, to a lesser extent, in libraries with more staff and a teacher-librarian. In schools where teachers were more engaged with the $\mathrm{AC}$, libraries were somewhat more likely to put together resource packages for teachers or departments $(r=0.093)$ and to enter AC alignments into MARC records $(r=0.144)$.

Descriptive statistics for the five continuous predictor variables and Teacher-Librarian (which was dichotomous) are presented in Table 2, and inter-correlations amongst these are in Table 3.

Sixty-four per cent $(n=356)$ of respondents indicated they worked in a library with at least one teacher-librarian.

Table 2. Descriptive statistics for continuous predictors, and teacher-librarian (dichotomous)

\begin{tabular}{lllll}
\hline \hline & $\mathrm{N}$ & Min & Max & Mean (SD) \\
\hline School Curriculum Activity & 512 & 1 & 4 & $3.13(0.64)$ \\
Teacher Approach & 558 & 1 & 5 & $3.05(0.93)$ \\
Library Engagement & 556 & 1 & 4 & $2.5(0.63)$ \\
School enrolment & 560 & 1 & 7 & $2.99(1.3)$ \\
Teacher Librarian & 560 & 0 & 1 & $0.64(0.48)$ \\
Library Staff & 560 & 1 & 5 & $1.87(0.76)$ \\
\hline \hline
\end{tabular}

Larger schools tended to have more library engagement, more library staff, and to have a teacher-librarian. Likewise, libraries with more staff and a teacher-librarian were more likely to be engaged libraries. Teachers were more likely to approach these libraries.

Table 3. Simple correlations (Pearson's r) amongst predictors

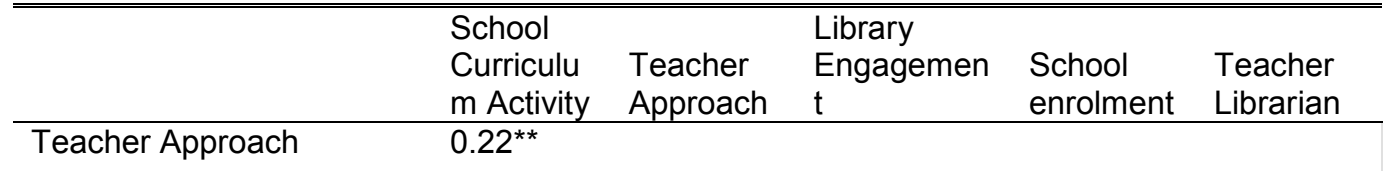




\begin{tabular}{llllll} 
Library Engagement & 0.08 & $0.45^{\star *}$ & & & \\
School enrolment & 0.04 & 0.02 & $0.24^{\star *}$ & & \\
Teacher Librarian & $-0.11^{*}$ & -0.01 & $0.24^{* *}$ & $0.23^{\star *}$ & \\
Library Staff & 0.03 & $0.09^{\star}$ & $0.24^{\star *}$ & $0.53^{\star *}$ & $0.38^{\star *}$ \\
\hline \hline
\end{tabular}

** Correlation is significant at the 0.01 level (2-tailed)

* Correlation is significant at the 0.05 level (2-tailed)

Schools that actively engaged teachers in the Australian Curriculum were more likely to have teachers that approached the library, but somewhat less likely to have a teacher-librarian.

Figure 4 shows the frequency distribution of library staffing, and reveals that $52 \%$ of respondents came from libraries with less than two staff. The frequency distribution of school enrolments can be seen in Figure 5, showing that $70 \%$ of respondents came from schools with 800 students or less.

Table 4 and Table 5 display the relationship between continuous predictors and school level and school sector, respectively.

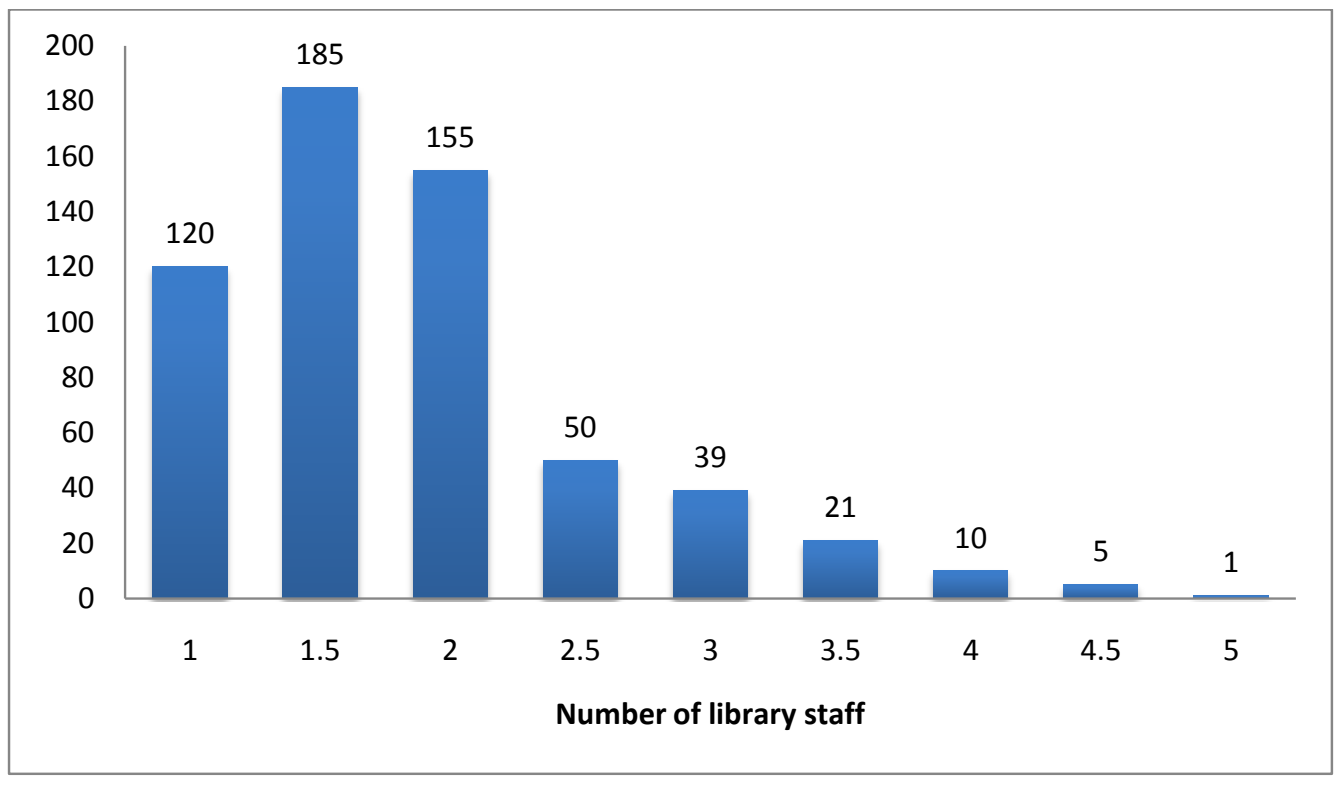

Figure 4 Frequency distribution of library staff

Libraries were more active in secondary schools than primary schools, but teachers in secondary schools were less likely to approach the library than in either primary or combined schools. Libraries were more likely to be curriculum-engaged and teachers were more likely to approach the library in Catholic schools compared to Government schools. 


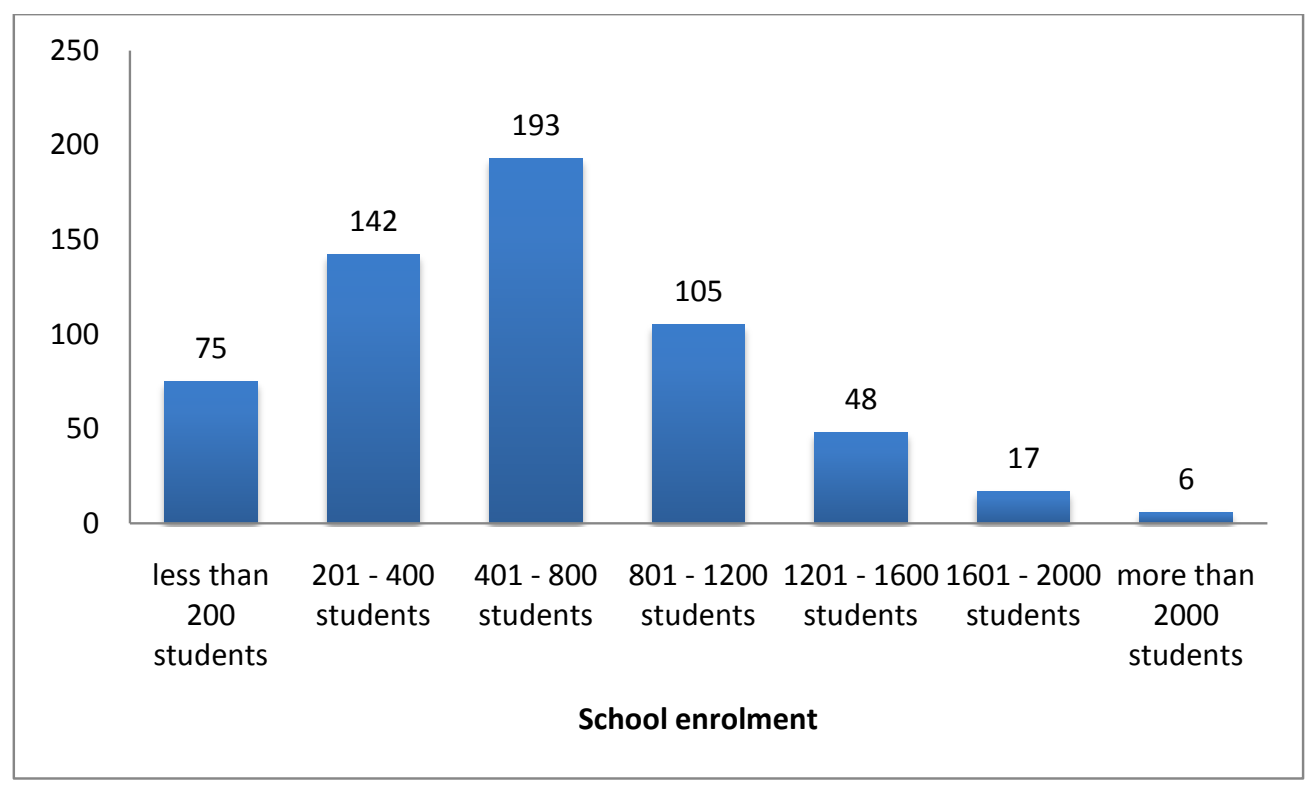

Figure 5 Frequency distribution of enrolment size

School curriculum activity did not differ across school level, and whilst there was a significant effect of school sector on school curriculum activity, no pairwise comparisons reached significance. There was a trend for Government schools to be less active in the curriculum than Catholic or Independent schools.

Table 4. Relationship between continuous predictors and school level

\begin{tabular}{lllll}
\hline \hline & Primary & Secondary & Combined & Significance \\
\hline Library Engagement & $2.42^{\mathrm{a}}$ & $2.6^{\mathrm{b}}$ & 2.58 & $\mathrm{~F}(2,553)=5.55^{*}$ \\
Teacher Approach & $3.17^{\mathrm{a}}$ & $2.79^{\mathrm{b}}$ & $3.08^{\mathrm{a}}$ & $\mathrm{F}(2,555)=8.6^{* *}$ \\
School Curriculum Activity & 3.1 & 3.13 & 3.2 & $\mathrm{~F}(2,509)=0.82$ \\
School enrolment & $2.31^{\mathrm{a}}$ & $3.87^{\mathrm{b}}$ & $3.62^{\mathrm{b}}$ & $\mathrm{F}(2,557)=134.6^{* *}$ \\
Library Staff & $1.54^{\mathrm{a}}$ & $2.25^{\mathrm{b}}$ & $2.26^{\mathrm{b}}$ & $\mathrm{F}(2,557)=78.74^{* *}$ \\
\hline \hline
\end{tabular}

Superscripts indicate columns differing significantly in Bonferroni post-hoc tests

** Correlation is significant at the 0.01 level (2-tailed)

${ }^{*}$ Correlation is significant at the 0.05 level (2-tailed)

Both secondary and combined schools had higher enrolments than primary schools.

Enrolments were also likely to be higher in Independent schools than either Catholic or Government schools. 
Library staffing was likely to be higher in secondary and combined schools than in primary schools. Independent schools had the most library staff and government schools had the least.

Table 5. Relationship between continuous predictors and school sector

\begin{tabular}{lllll}
\hline \hline & Government & Catholic & Independent & $F$ \\
\hline Library Engagement & $2.43^{\mathrm{a}}$ & $2.6^{\mathrm{b}}$ & 2.59 & $\mathrm{~F}(2,553)=4.83^{*}$ \\
Teacher Approach & $2.95^{\mathrm{a}}$ & $3.21^{\mathrm{b}}$ & 3.18 & $\mathrm{~F}(2,555)=4.86^{\star}$ \\
School Curriculum Activity & 3.07 & 3.24 & 3.19 & $\mathrm{~F}(2,509)=3.26^{\star}$ \\
School enrolment & $2.75^{\mathrm{a}}$ & $3.02^{\mathrm{a}}$ & $3.66^{\mathrm{b}}$ & $\mathrm{F}(2,557)=22.84^{* *}$ \\
Library staff & $1.68^{\mathrm{a}}$ & $1.99^{\mathrm{b}}$ & $2.3^{\mathrm{c}}$ & $\mathrm{F}(2,557)=33.19^{\star *}$ \\
\hline \hline
\end{tabular}

Different superscripts indicate columns differing significantly in Bonferroni post-hoc tests

** Significant at the 0.01 level (2-tailed)

* Significant at the 0.05 level (2-tailed)

There was a significant relationship between number of teacher-librarians and school level $($ Chi-sq(2) $=21.68, p<.001)$. Secondary schools were almost 1.4 times more likely to have a teacher-librarian than primary schools. There was also a significant relationship between number of teacher-librarians and school sector $(\operatorname{Chi}-s q(2)=7.04, p=0.03)$. Catholic schools were almost 1.23 times more likely than Government schools and 1.15 times more likely than Independent schools to have a teacher-librarian.

\section{Outcome}

An index was constructed to measure PVA. Principal Components Analysis was used to confirm the item structure of the index, and Cronbach's alpha was used to assess internal consistency. See Appendix B for details.

The PVA index was a composite of six standardised items, so its measurement scale had no inherent meaning. As such, it was standardised to facilitate interpretation by centring its mean on zero $(S D=1)$. Its maximum value was 1.25 and minimum was -4.07 .

\section{Univariate Analyses}

Table 6 displays correlations between PVA and the set of continuously scaled predictors. PVA was significantly related to higher library engagement, teacher approach, the presence of a teacher-librarian, and school curriculum activity.

Table 6. Simple correlations (Pearson's $r$ ) between predictors and perceived value of alignment 


\begin{tabular}{ll}
\hline \hline Predictor & $r$ \\
\hline School Curriculum Activity & $0.087^{*}$ \\
Teacher Approach & $0.140^{* *}$ \\
Library Engagement & $0.255^{* *}$ \\
School enrolment & 0.044 \\
Teacher Librarian & $0.138^{* *}$ \\
Library Staff & 0.016 \\
\hline \hline${ }^{* *}$ Correlation is significant at the 0.01 level (2-tailed) \\
${ }^{*}$ Correlation is significant at the 0.05 level (2-tailed)
\end{tabular}

A two-way (School Level * School Sector) ANOVA was performed to examine the relationship between school level and sector and perceived value of alignment. Marginal means are displayed in Table 7. There was no significant school level $(F(2,551)=1.15$, $\mathrm{p}=0.32)$ or school sector $(F(2,551)=2.34, \mathrm{p}=0.098)$ effects and no interaction $(F(4,551)=0.74$, p=n.s.).

Table 7. Marginal means of PVA over school level and school sector

\begin{tabular}{lllll}
\hline \hline & Government & Catholic & Independent & School Sector Total \\
\hline Primary & 0.002 & 0.05 & 0.054 & 0.035 \\
Secondary & -0.17 & 0.106 & 0.067 & 0.001 \\
Combined & 0.009 & 0.576 & 0.085 & 0.223 \\
School Level Total & -0.053 & 0.244 & 0.069 & \\
\hline \hline
\end{tabular}

\section{Multivariate Analyses}

To examine the unique effects of the significant predictor variables identified above, a Multiple Regression was performed with school curriculum activity, teacher approach, library engagement, and teacher-librarian entered into a single step to predict PVA.

A significant Multiple-R of 0.289 was found $(F(4,505)=11.47, \mathrm{p}<.001)$, accounting for $8.3 \%$ of variance in PVA.

Table 8 reveals that only engaged libraries and teacher-librarians demonstrated a significant relationship with PVA, both of which were positive, and uniquely accounted for $2.97 \%$ and $0.7 \%$ of variance respectively. 
Table 8. Regression coefficients in prediction of perceived value of alignment

\begin{tabular}{llll}
\hline \hline & $\mathrm{B}($ Std Error) & Beta & $\mathrm{t}$ \\
\hline Intercept & $-1.479(0.271)$ & & $-5.46^{* *}$ \\
School Curriculum & $0.099(0.068)$ & 0.064 & 1.45 \\
Activity & & & \\
Teacher Approach & $0.097(0.053)$ & 0.089 & 1.83 \\
Library Engagement & $0.316(0.078)$ & 0.197 & $4.05^{* *}$ \\
Teacher Librarian & $0.182(0.092)$ & 0.087 & $1.97^{*}$ \\
\hline \hline
\end{tabular}

** Correlation is significant at the 0.01 level (2-tailed)

${ }^{*}$ Correlation is significant at the 0.05 level (2-tailed)

\section{Discussion}

In the context of an unfolding national curriculum, Australian school libraries have expressed a need for services to support teaching staff by resourcing the curriculum with targeted, quality materials (Kennedy, 2013). Whilst SCIS is well placed to provide such a service, its viability depends on the extent of this demand and whether it is broad or being driven by narrow sub-sets of the school library community.

The current study described a survey of 586 Australian school libraries examining possible school-level and library-level factors that may be associated with libraries' perception of the value of resource alignment. For example, it was proposed that demand might be higher in libraries staffed by at-least one teacher-librarian. It was also proposed that an important library-level factor affecting demand for resource alignment may be library curriculumengagement - the extent of libraries' current efforts to resource the curriculum through active engagement with teachers.

\section{Curriculum-Engaged Libraries}

Active engagement took a number of forms, with at least half of the responding libraries doing each of the measured activities at least once per term. The exception was entering curriculum alignment data into catalogue records, which was performed by a minority of libraries. This was an interesting result, given it is an activity that directly contributes to the discoverability and re/use of the curriculum resource links. At least once per term, a strong majority of schools sought information from teaching staff about their resourcing needs, recommended resources to staff, and purchased resources specifically for their relevance to AC outcomes.

The extent to which teachers actively approached the library was consistently the factor most associated with libraries' engagement practices. It is not clear whether teacher activity 
prompts libraries to be more active, whether library activity prompts teachers to approach the library, or a bit of both. Further research could explore the library activities that are most associated with encouraging teachers' use of the library, and examine the direction of this effect.

Engaged libraries were more commonly seen in larger schools and schools that had libraries with more staff and at least one teacher-librarian. This makes sense: greater staffing means more opportunities for work on 'value-adding' projects, and such work will be guided by and benefit from the experience and training of staff. Larger schools had more library staff and were more likely to have a teacher-librarian, which is likely due to the demand to maintain a workable staff-student ratio and possibly greater library funding. It is possible school size impacts library engagement through library staffing factors, although there may also be cultural factors in larger schools that promote active engagement by libraries.

Engaged libraries were more likely in secondary schools than primary schools, and more likely in Catholic than Government schools. Catholic and secondary schools were more likely to have a teacher-librarian, and secondary schools were larger than primary schools so, again, it is possible the impact of these broad school-level factors is via library staffing; although cultural factors in these school settings may also impact on library engagement.

\section{Perceived Value of Alignment}

Of all the factors hypothesised to impact on a school library's perception of the value of curriculum-aligned resources, only two library-level factors - library curriculum-engagement and having a teacher-librarian on staff - were uniquely and directly related. Whilst teachers' engagement with the library and the school's level of curriculum activity were initially related to perceived value of alignment, these factors became non-significant when co-varied with the previous two factors, possibly suggesting a mediation relationship.

Whilst not tested explicitly, the current findings suggest a causal model such as that presented in エラー! 参照元が見つかりません。：a library's perception of the value of resource alignment is most directly impacted by a motivated teacher-librarian and/or existing practices to promote an engaged library. Teacher-librarians and engaged libraries are more commonly found in larger schools with larger libraries (more often found in secondary schools and Independent schools), Catholic schools, and secondary schools. Teacherlibrarians are also more likely to promote engaged libraries. If the library is proactive with teachers, teachers are more likely to approach the library, and it possible this relationship works in both directions. Teachers, in turn, are slightly less inclined to approach the library in secondary schools, but more inclined to do so in Catholic schools and schools with a strong emphasis on implementing the Australian Curriculum in teaching activities. The latter schools are somewhat less likely to have a TL in the school library. The interpretation of this 
last finding is unclear: it is possible schools whose principal is focused on AC implementation may deprioritise library staffing or be less supportive of traditional library staffing models.

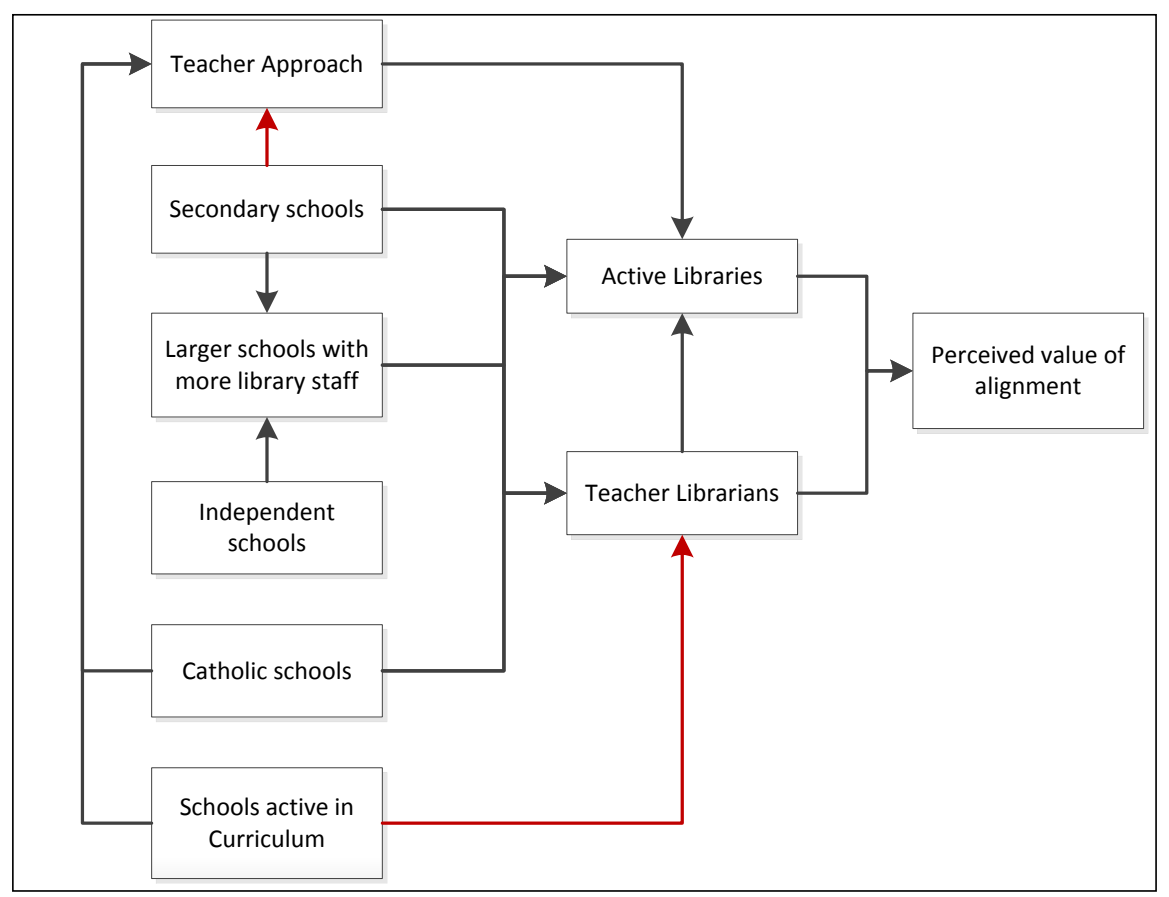

Figure 6. Proposed model of factors driving perceived value of alignment

The current study reveals that the demand for resource alignment as a potential service for school libraries is not coming from broad types of schools in terms of their size, sector or level. It is coming from particular kinds of libraries - those whose staff and practices reveal a culture of engagement and collaboration.

The indexes constructed in this study were intended to be succinct measures of the constructs of library engagement, teacher approach, and school curriculum activity. However, given the potential utility of these notions, future research may benefit from further exploring and expanding on these concepts and how best to measure them.

The notion of library engagement was introduced in the current study to answer particular questions. However, this is a potentially interesting construct that may have wider applicability in the area of evidence-based practice for school libraries. What practices define an engaged-library, and how do each of these factors relate to the measureable benefits 
school libraries offer for teaching, learning and broader school outcomes? Provision of curriculum-aligned resources may well be one such factor. 


\section{References}

Adamich, T. (2010). Materials-to-standards alignment: how to "chunk" a whole cake and even use the "crumbs": state standards alignment models, learning objectives, and formative assessment-methodologies and metadata for education. International Journal of Information and Communication Technology Education, 6( 2), pp. 62-75, viewed 5 May 2016, http://www.nwoet.org/tins/Materials-tostandards\%20alignment\%20article\%20IJICTE09102009.pdf

Australian Bureau of Statistics [ABS]. (2016). Table 35a Summary of School Characteristics, 2012-2015, Australian Bureau of Statistics, viewed 25 May 2016

http://www.abs.gov.au/ausstats/subscriber.nsf/log?openagent\&table $\% 2035 \mathrm{a} \% 20$ summary $\%$ 20of\%20school\%20characteristics, \%202012-

2015.xls\&4221.0\&Data\%20Cubes\&8381AFD2FE3CDB61CA257F790033B5FA\&0\&2015\&1 8.03.2016\&Latest

Australian Library and Information Association. (2014a). Future of the Library and Information Science Profession: School Libraries, ALIA, viewed 6 May 2016, www.alia.org.au/futureoftheprofession

Australian Library and Information Association. (2014b). Teacher Librarian Practice for the Australian Professional Standards, ALIA, viewed 6 May 2016, https://www.alia.org.au/sites/default/files/AITSL\%20Standards\%20for\%20teacher\%20libraria n\%20practice\%202014.pdf

Australian School Library Association. (2014). Policy Statement - School Library Bill of Rights, Australian School Library Association, viewed 22 May 2016, http://www.asla.org.au/policy/bill-of-rights.aspx

Australian Government. (2014). Review of the Australian curriculum: final report, Department of Education, viewed 5 January 2016,

https://docs.education.gov.au/system/files/doc/other/review of the national curriculum fina report.pdf

Australian Curriculum, Assessment and Reporting Authority. (2015a). Curriculum, ACARA, viewed 18 May 2016, http://www.acara.edu.au/curriculum/curriculum.html

Australian Curriculum, Assessment and Reporting Authority. (2015b). F - 10 Overview:

Structure, ACARA, viewed 19 May 2016,

http://www.australiancurriculum.edu.au/overview/structure 
Batiste, W., Walker, S., \& Smeed, J.L. (2015). The relationship between teachers' perceptions of their principal's leadership and the implementation of the National Curriculum. Leading and Managing, 21(1), pp. 69-85

Carr, J.F., \& Harris, D.E. (2001). Succeeding with standards: linking curriculum, assessment, and action planning, Association for Supervision and Curriculum Development, Alexandria, VA.

Demski, J. (2009). Free at Last: By creating a user-generated, ever-growing library of original digital content, an Arizona school district has liberated its teachers from the restraints of a textbook-driven curriculum model. THE Journal (Technological Horizons In Education), 36(6), pp. 39-44, viewed 18 May 2016, https://www.questia.com/library/journal/1G1-202365182/free-at-last-by-creating-a-usergenerated-ever-growing

Education Council. (2015). National stem school education strategy: a comprehensive plan for science, technology, engineering and mathematics education in Australia, Education Council, viewed 21 December 2015, http://www.educationcouncil.edu.au/site/DefaultSite/filesystem/documents/National\%20STE M\%20School\%20Education\%20Strategy.pdf

Hughes, H. (2014). School Libraries, Teacher-Librarians and Student Outcomes: Presenting and Using the Evidence. School Libraries Worldwide, 20(1), pp. 29-50

IBM Corp. (2016). IBM SPSS Statistics for Windows, Version 24.0. Armonk, NY: IBM Corp.

La Marca, S. (2013). Curriculum, Culture and Community: The School Library and the General Capabilities of the Australian Curriculum, In International Association of School Librarianship. Selected Papers from the annual conference. International Association of School Librarianship.

Lowe, K.R. (2001). Resource alignment: Providing curriculum support in the school library media center. Knowledge Quest, 30(2), p. 27-32

Kennedy, C. (2013). School library collections survey 2013. Connections, 88, pp. 10-11, viewed 18 May 2016,

http://www2.curriculum.edu.au/scis/connections/issue 88 2014/articles/school library colle ctions survey 2013.html

MacKenzie, A. (2012). Integrating Year 6 History Curriculum and the library', ACCESS, Nov, pp. $32-33$ 
Ministerial Council on Education, Employment, Training and Youth Affairs. (2003). Learning Architecture Framework: Learning in an Online World, Curriculum Corporation, viewed 21 December 2015, http://www.scseec.edu.au/site/DefaultSite/filesystem/documents/Reports\%20and\%20publica tions/Archive\%20Publications/ICT/LOW-LearningArchitectureFWork.pdf

Mitchell, P. (2011). Resourcing 21st century online Australian Curriculum: The role of school libraries. FYI, Autumn, pp. 10-15

Rawson, C.H. (2014). Every Flower In The Garden: Collaboartion between school librarians and science teachers. School Libraries Worldwide, 20(1), pp. 20-28

Softlink Australia. (2015). 2015 Australian School Library Survey, Softlink, viewed 18 May 2016,

http://www.softlinkint.com/assets/img/banners/2015 Softlink ANZ School Library Survey $\underline{\text { Report.pdf }}$

Squires, D. (2012). Curriculum alignment research suggests that alignment can improve student achievement. The Clearing House: A Journal of Educational Strategies, Issues and Ideas, 85(4), pp. 129-135

United Nations Educational, Scientific and Cultural Organization. (2016). UNESCO/IFLA School Library Manifesto, United Nations Educational, Scientific and Cultural Organization, viewed 20 May 2016, http://www.unesco.org/webworld/libraries/manifestos/school manifesto.html

Varanasi, R. (2011). New curriculum in NSW schools. Part 2: Teacher librarians partnering curriculum change. Scan: The Journal For Educators, 30(4), p.36 


\section{Appendix A - Questionnaire items}

\begin{tabular}{|c|c|c|c|}
\hline \multicolumn{2}{|c|}{ Question } & \multirow{2}{*}{$\begin{array}{l}\text { Options/Sub-items } \\
\text { Teacher Librarian; Librarian; Library Technician; School } \\
\text { assistant/library officer; Teacher; Principal/Assistant } \\
\text { Principal/Other }\end{array}$} & \multirow{2}{*}{$\begin{array}{l}\text { Response } \\
\text { Type } \\
\text { Single choice }\end{array}$} \\
\hline 1 & $\begin{array}{l}\text { What is your current } \\
\text { role? }\end{array}$ & & \\
\hline 2 & $\begin{array}{l}\text { Do you currently } \\
\text { work in your school } \\
\text { library? }\end{array}$ & Yes; No & Single choice \\
\hline 3 & $\begin{array}{l}\text { What is the total } \\
\text { enrolment at your } \\
\text { school? }\end{array}$ & $\begin{array}{l}1 \text { - Less than } 200 \\
2-201 \text { to } 400 \\
3-401 \text { to } 800 \\
4-801 \text { to } 1200 \\
5-1201 \text { to } 1600 \\
6-1601 \text { to } 2000 \\
7 \text { - More than } 2000\end{array}$ & $\begin{array}{l}\text { Seven point } \\
\text { scale }\end{array}$ \\
\hline 4 & School level & Primary; Secondary; Combined Primary/Secondary; Other & Single choice \\
\hline 5 & School sector & Government; Catholic; Independent; Other & Single choice \\
\hline 6 & School location & ACT; NSW; NT; QLD; SA; Tas; Vic; WA & Single choice \\
\hline 7 & $\begin{array}{l}\text { Who else works in } \\
\text { your school library }\end{array}$ & $\begin{array}{l}\text { Teacher Librarian; Librarian; Library Technician; School } \\
\text { assistant/library officer; Teacher; Principal/Assistant } \\
\text { Principal/Other }\end{array}$ & $\begin{array}{l}\text { Multiple } \\
\text { responses }\end{array}$ \\
\hline 8 & $\begin{array}{l}\text { How is the Australian } \\
\text { Curriculum (AC) } \\
\text { used in your school? }\end{array}$ & $\begin{array}{l}\text { a. Teachers develop units of work to specifically address } \\
\text { AC outcomes } \\
\text { b. Teachers develop a unit of work, then go to the AC to } \\
\text { see what outcomes it addresses } \\
\text { c. Teacher evaluation is tied to how they cover AC } \\
\text { outcomes } \\
\text { d. Teachers use resources that were specifically designed } \\
\text { to address AC outcomes (such as textbooks) }\end{array}$ & $\begin{array}{l}\text { Five point } \\
\text { scale: Never } \\
\text { to Always }\end{array}$ \\
\hline 9 & $\begin{array}{l}\text { How often do } \\
\text { teachers in your } \\
\text { school do the } \\
\text { following? }\end{array}$ & $\begin{array}{l}\text { a. Inform the library about units of work they will be } \\
\text { teaching } \\
\text { b. Approach the library with resourcing needs } \\
\text { c. Approach the library for resources aligned to a } \\
\text { particular Australian Curriculum outcome } \\
\text { d. Use the library catalogue to find resources for their } \\
\text { needs }\end{array}$ & $\begin{array}{l}\text { Five point } \\
\text { scale: Never } \\
\text { to Most days }\end{array}$ \\
\hline 10 & $\begin{array}{l}\text { How often does the } \\
\text { library do the } \\
\text { following? }\end{array}$ & $\begin{array}{l}\text { a. Research or inquire about staff resource needs } \\
\text { b. Recommend resources to staff } \\
\text { c. Put resource packages together for teachers or } \\
\text { departments } \\
\text { d. Review the collection to find resources that are relevant } \\
\text { to a particular Australian Curriculum outcome } \\
\text { e. Purchase new resources because they are relevant to a } \\
\text { particular Australian Curriculum outcome } \\
\text { f. Examine the collection for gaps in Australian Curriculum } \\
\text { coverage } \\
\text { g. Make special collections of resources aligned to } \\
\text { Australian Curriculum outcomes (eg Libguides, reading } \\
\text { lists, class lists) } \\
\text { h. Make special collections of resources for year levels } \\
\text { i. Enter Australian Curriculum alignment data into the } \\
\text { MARC catalogue record of a resource }\end{array}$ & $\begin{array}{l}\text { Five point } \\
\text { scale: Never } \\
\text { to Weekly }\end{array}$ \\
\hline 11 & $\begin{array}{l}\text { Please rate your } \\
\text { agreement with the } \\
\text { following statements }\end{array}$ & $\begin{array}{l}\text { a. If a resource is relevant to an AC outcome, teachers } \\
\text { are more likely to use it } \\
\text { b. The library is currently looking for ways to provide staff }\end{array}$ & $\begin{array}{l}\text { Four point } \\
\text { scale: } \\
\text { Disagree to }\end{array}$ \\
\hline
\end{tabular}




\begin{tabular}{|c|c|c|c|}
\hline \multicolumn{2}{|c|}{ Question } & Options/Sub-items & $\begin{array}{l}\text { Response } \\
\text { Type }\end{array}$ \\
\hline & $\begin{array}{l}\text { about the library and } \\
\text { the Australian } \\
\text { Curriculum (AC). }\end{array}$ & with resources matched to the $A C$ & $\begin{array}{l}\text { Strongly } \\
\text { Agree }\end{array}$ \\
\hline 12 & $\begin{array}{l}\text { If SCIS provided your } \\
\text { library with } \\
\text { data about how } \\
\text { resources align to } \\
\text { the Australian } \\
\text { Curriculum... }\end{array}$ & $\begin{array}{l}\text { a. It would be of use to our school } \\
\text { b. It would increase the profile of the library } \\
\text { c. Library staff would be able to add extra value to } \\
\text { teaching and learning in the school }\end{array}$ & $\begin{array}{l}\text { Four point } \\
\text { scale: } \\
\text { Disagree to } \\
\text { Strongly } \\
\text { Agree }\end{array}$ \\
\hline 13 & How likely is it that you & library would use alignments created by SCIS & $\begin{array}{l}\text { Five point } \\
\text { scale: } \\
\text { Unlikely to } \\
\text { Highly likely }\end{array}$ \\
\hline
\end{tabular}




\section{Appendix B - Scale Construction}

Two Principal Components Analyses (PCA) with Varimax rotation were used to confirm the validity of scale construction, one for predictor variables, and one for the outcome variable. The number of factors was determined by Eigenvalues over one, and scree plots were also examined for optimal cut-points.

\section{Predictor Variables}

Items from survey questions eight, nine, and ten were used to measure School Curriculum Activity, Teacher Approach, and Library Engagement, respectively. See Table 9 for descriptive statistics.

Table 9. Descriptive statistics for predictor variables

\begin{tabular}{|c|c|c|c|c|c|}
\hline \multicolumn{2}{|c|}{ Question item } & $\mathrm{N}$ & Min & Max & Mean (SD) \\
\hline Q8a & $\begin{array}{l}\text { Teachers develop units addressing AC } \\
\text { outcomes }\end{array}$ & 492 & 1 & 4 & $3.46(0.71)$ \\
\hline Q8b & $\begin{array}{l}\text { Teachers develop units of work, then consult } \\
\text { AC }\end{array}$ & 450 & 1 & 4 & $2.19(1.1)$ \\
\hline Q8c & Teacher evaluation tied to $A C$ coverage & 439 & 1 & 4 & $3.15(0.9)$ \\
\hline Q8d & $\begin{array}{l}\text { Teachers use resources designed for } \mathrm{AC} \\
\text { alignment }\end{array}$ & 502 & 1 & 4 & $2.81(0.9)$ \\
\hline Q9a & Teachers inform library about units of work & 553 & 1 & 5 & $2.74(1.09)$ \\
\hline Q9b & $\begin{array}{l}\text { Teachers approach library with resourcing } \\
\text { needs }\end{array}$ & 555 & 1 & 5 & $3.59(1.2)$ \\
\hline Q9c & $\begin{array}{l}\text { Teachers approach library for aligned } \\
\text { resources }\end{array}$ & 549 & 1 & 5 & $3.08(1.19)$ \\
\hline Q9d & Teachers use library catalogue & 533 & 1 & 5 & $2.77(1.32)$ \\
\hline Q10a & Research/inquire about staff resource needs & 509 & 1 & 4 & $2.72(0.88)$ \\
\hline Q10b & Recommend resources to staff & 530 & 1 & 4 & $3.2(0.84)$ \\
\hline Q10c & $\begin{array}{l}\text { Resource packages for teachers or } \\
\text { departments }\end{array}$ & 505 & 1 & 4 & $2.36(0.86)$ \\
\hline Q10d & Review the collection for aligned resources & 434 & 1 & 4 & $2.38(0.88)$ \\
\hline Q10e & Purchase aligned resources & 492 & 1 & 4 & $2.62(0.77)$ \\
\hline Q10f & Examine the collection for gaps & 385 & 1 & 4 & $2.26(0.87)$ \\
\hline Q10g & Special collections of AC aligned resources & 404 & 1 & 4 & $2.07(0.95)$ \\
\hline Q10h & $\begin{array}{l}\text { Special collections of resources for year } \\
\text { levels }\end{array}$ & 491 & 1 & 4 & $2.31(0.91)$ \\
\hline Q10i & Enter AC alignment into the MARC records & 407 & 1 & 4 & $1.44(0.9)$ \\
\hline
\end{tabular}

When PCA was performed, the scree plot suggested a natural cut-point after three factors, but there were four factors with an eigenvalue over one, collectively accounting $54.85 \%$ of variance. Rotated factor loadings can be found in Table 10.

Factor four accounted for only $8.11 \%$ variance and had loadings of 0.68 and 0.52 on only two items. Because of this, and because the meaning of this scale was not clear, it was removed from consideration. 
The remaining factors reflected the hypothesised factor structure, with active library items (10a to 10h) loading on factor one, teacher approach items (9a to 9d) loading on factor two, and school curriculum activity items (8a to $8 d$ ) loading on factor three.

The three scales were constructed as an unweighted average of constituent items. Internal consistency was measured via Cronbach's alpha, and was considered adequate at 0.62 , 0.77, and 0.89 for School Curriculum Activity, Teacher Approach, and Library Engagement, respectively.

Table 10. Rotated component matrix for predictor variables

\begin{tabular}{|c|c|c|c|c|c|}
\hline \multicolumn{2}{|c|}{ Question item } & Factor 1 & Factor 2 & Factor 3 & Factor 4 \\
\hline Q8a & $\begin{array}{l}\text { Teachers develop units addressing AC } \\
\text { outcomes }\end{array}$ & 0.041 & 0.084 & 0.800 & -0.030 \\
\hline Q8b & $\begin{array}{l}\text { Teachers develop units of work, then consult } \\
\text { AC }\end{array}$ & -0.075 & -0.050 & 0.189 & 0.683 \\
\hline Q8c & Teacher evaluation tied to AC coverage & -0.027 & 0.100 & 0.818 & 0.078 \\
\hline Q8d & $\begin{array}{l}\text { Teachers use resources designed for } \mathrm{AC} \\
\text { alignment }\end{array}$ & 0.044 & 0.020 & 0.525 & 0.431 \\
\hline Q9a & Teachers inform library about units of work & 0.111 & 0.768 & -0.001 & 0.143 \\
\hline Q9b & $\begin{array}{l}\text { Teachers approach library with resourcing } \\
\text { needs }\end{array}$ & 0.167 & 0.799 & 0.126 & -0.077 \\
\hline Q9c & $\begin{array}{l}\text { Teachers approach library for aligned } \\
\text { resources }\end{array}$ & 0.176 & 0.741 & 0.266 & 0.055 \\
\hline Q9d & Teachers use library catalogue & 0.150 & 0.646 & -0.055 & 0.080 \\
\hline $\begin{array}{l}\text { Q10 } \\
\text { a }\end{array}$ & Research/inquire about staff resource needs & 0.640 & 0.207 & -0.023 & -0.053 \\
\hline $\begin{array}{l}\text { Q10 } \\
b\end{array}$ & Recommend resources to staff & 0.605 & 0.313 & 0.058 & -0.234 \\
\hline $\begin{array}{l}\text { Q10 } \\
\mathrm{C}\end{array}$ & $\begin{array}{l}\text { Resource packages for teachers or } \\
\text { departments }\end{array}$ & 0.629 & 0.265 & -0.027 & 0.269 \\
\hline $\begin{array}{l}\text { Q10 } \\
d\end{array}$ & Review the collection for aligned resources & 0.765 & 0.022 & 0.031 & 0.019 \\
\hline $\begin{array}{l}\text { Q10 } \\
\text { e }\end{array}$ & Purchase aligned resources & 0.662 & 0.062 & 0.091 & 0.010 \\
\hline $\begin{array}{l}\text { Q10f } \\
\text { Q10 }\end{array}$ & $\begin{array}{l}\text { Examine the collection for gaps } \\
\text { Special collections of } A C \text { aligned resources }\end{array}$ & $\begin{array}{l}0.746 \\
0.589\end{array}$ & $\begin{array}{l}0.027 \\
0.155\end{array}$ & $\begin{array}{l}0.027 \\
-0.096\end{array}$ & $\begin{array}{l}0.064 \\
0.424\end{array}$ \\
\hline $\begin{array}{l}\mathrm{g} \\
\text { Q10 } \\
\mathrm{h}\end{array}$ & Special collections of resources for year levels & 0.605 & 0.235 & -0.055 & 0.308 \\
\hline Q10i & Enter AC alignment into the MARC records & 0.276 & 0.231 & -0.035 & 0.524 \\
\hline
\end{tabular}




\section{Outcome Variable}

Items from survey questions 11 to 13 were used to construct a Perceived Value of Alignment index. Descriptive statistics for these items can be found Table 11.

Table 11. Descriptive statistics and factor loadings for raw outcome items

\begin{tabular}{|c|c|c|c|c|c|c|}
\hline \multicolumn{2}{|c|}{ "Question item } & \multirow{2}{*}{$\begin{array}{l}\mathrm{N} \\
571\end{array}$} & \multirow{2}{*}{$\begin{array}{l}\text { Min } \\
1\end{array}$} & \multirow{2}{*}{\begin{tabular}{|l} 
Max \\
5
\end{tabular}} & \multirow{2}{*}{$\begin{array}{l}\text { Mean } \\
\text { (SD) } \\
4.20 \\
(0.86)\end{array}$} & \multirow{2}{*}{$\begin{array}{l}\begin{array}{l}\text { Factor } \\
\text { Loading }\end{array} \\
0.667\end{array}$} \\
\hline Q13 & Library would use SCIS alignments & & & & & \\
\hline Q12a & It would be of use to our school & 573 & 1 & 4 & $\begin{array}{l}3.48 \\
(0.66)\end{array}$ & 0.888 \\
\hline Q12b & $\begin{array}{l}\text { It would increase the profile of the } \\
\text { library }\end{array}$ & 562 & 1 & 4 & $\begin{array}{l}3.33 \\
(0.81)\end{array}$ & 0.866 \\
\hline Q12b & Add value to teaching and learning & 572 & 1 & 4 & $\begin{array}{l}3.48 \\
(0.69)\end{array}$ & 0.902 \\
\hline Q11a & $\begin{array}{l}\text { Teachers are more likely to use } \\
\text { aligned resources }\end{array}$ & 569 & 1 & 4 & $\begin{array}{l}3.33 \\
(0.68)\end{array}$ & 0.45 \\
\hline Q11b & $\begin{array}{l}\text { Library is looking for ways to } \\
\text { provide aligned resources }\end{array}$ & 559 & 1 & 4 & $\begin{array}{l}3.09 \\
(0.85)\end{array}$ & 0.566 \\
\hline
\end{tabular}

As hypothesised, PCA revealed a single factor with an eigenvalue over one, accounting for $55.3 \%$ of variance. All items demonstrated factor loadings over 0.45 (see Table 11).

Scales were standardised to resolve differences in scaling (five points versus four). They were then combined as an unweighted average. The final Perceived Value of Alignment index was calculated by standardizing that aggregate score. Internal consistency was considered adequate (Cronbach's alpha $=0.816)$. 


\section{Biography: Dr Ben Chadwick}

Dr Ben Chadwick is manager of the Schools Catalogue Information Service, or SCIS, at Education Services Australia. Ben has been at ESA since 2012, originally as a metadata analyst working on the linked-data Australian Education Vocabularies. Ben came to the information industries from a research career at the University Of Queensland, working in the area of psychological recovery from physical injuries. 